\title{
Social Networking in the Dimensions of Economic Welfare Based on Local Communities in Minangkabau as a Model of Empowerment for Islamic Communities
}

Muhamad Jamil ${ }^{1}$, M Bahri Ghazali², Hasan $\underset{\text { Jaafar }^{4}}{\text { Mumin }^{2}, \text { Syafrimen Syafril }^{2}, \text { Welhendri Azwar }}{ }^{3}$, Azhar

${ }^{1}$ Sekolah Tinggi Agama Islam Yayasan Tarbiyah Islamiyah Padang, Indonesia, ${ }^{2}$ Universitas Islam Negeri Raden Intan Lampung, Indonesia, ${ }^{3}$ Universitas Islam Negeri Imam Bonjol, Indonesia \& ${ }^{4}$ University College of Yayasan Pahang, Malaysia.

\begin{tabular}{|c|c|}
\hline ARTICLE INFO & ABSTRACT \\
\hline Article history: & \multirow{10}{*}{$\begin{array}{l}\text { The success of community empowerment programs is influenced by } \\
\text { efforts to re-interpret the community as an object of empowerment. } \\
\text { In traditional Minangkabau, a community is identical to the Kaum, a } \\
\text { group of people classified by matrilineal lineage. Solid relationships } \\
\text { and cooperation that are part of communal interaction in Kaum } \\
\text { significantly are instrumental in fulfilling social and personal needs. } \\
\text { This article tries to answer a fundamental question of how social } \\
\text { networks of economic welfare based on the Kaum as a model of } \\
\text { empowering Islamic society. To answer this question, the inductive } \\
\text { logic of multiple case designs is used by taking five (5) Kaum in } \\
\text { Nagari Tabek Patah as the locus of the study. This case study used } \\
\text { NVIVO in the data processing. This research reveals that kaum social } \\
\text { networks are formed naturally in the community, strengthened by } \\
\text { customary norms and laws, and become a controller in realizing } \\
\text { economic welfare. }\end{array}$} \\
\hline Received Dec 30, 2020 & \\
\hline Revised Jan 02, 2021 & \\
\hline Accepted Mar 15, 2021 & \\
\hline Keywords: & \\
\hline Social Network, & \\
\hline Local community, & \\
\hline Economic Welfare, & \\
\hline Empowerment Models. & \\
\hline Conflict of Interest: & \\
\hline None & \\
\hline
\end{tabular}

Funding:

None

Corresponding Author: Muhamad Jamil, Sekolah Tinggi Agama Islam Yayasan Tarbiyah Islamiyah Padang, Jl. Pramuka IV No 2 Lolong Belanti Kota Padang Provinsi Sumatera Barat-Indonesia. Phone (+62) 0751-7054551 E-mail: jamiljaey@gmail.com.

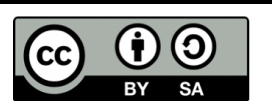

(C) Muhamad Jamil, M. M Bahri Ghazali, Hasan Mukmin, Syafrimen Syafril, Welhendri Azwar, Azhar Jaafar This is an open access article under the CC BY-SA 4.0 international license.

\section{Introduction}

Social capital is the accumulation of potential resources from social interactions, thereby facilitating individual actions in a structure, both horizontal and vertical, to guarantee; information, norms, values, networks, reciprocal links, collaboration, and etcetera, so it can be used for the purpose; justice, welfare, and community harmony in various fields of life (Fukuyama, 2012; Soc. Cap. Theory Res.," 2001; Rosalyn Harper, 2001; Djamaludin Ancok, 2003; Syahra, 2003; Haridison, 2013). In line with Hasbullah, the most important thing about social capital lies in how individuals' efforts to work together in building networks to achieve common goals (Abdullah, 2013). The common goal to be achieved is asset-based community development (Rhonda Phillips and Robert H. Pittman, 2009).

In Minangkabau, some communities have substantial social capital based on several indicators of social capital (Suharto, 2014). The community in question is the Kaum which collects several small families based on the matrilineal lineage. As a permanent community, the Kaum have various physical and non-physical 
assets. In the context of social capital, a Kaum has norms, beliefs, and strong social networks based on traditional and religious values (Jamil, 2019). All elements of social capital have a significant influence on the resilience of the community members when viewed in the dimensions of community empowerment, such as the dimensions of economy, politics, religion, culture, and so on (Barnett, 2012). The strength of the people in a community in these various dimensions is indicated by the fulfillment of personal and social needs as an indicator of welfare measured based on the existing norms of the community itself (Monografi Nagari Tabek Patah, 2015).

The question and focus to be answered in this research are how social networks in the economic welfare based on kaum as a traditional community in Minangkabau as a model of empowering Islamic society.

\section{Literature Review}

\subsection{Model of Community Empowerment}

In community empowerment, a model is understood in various ways. Some understand it as a strategy, process, approach, and others. The model is not static, but the model includes all the creativity of macro, mezzo, and micro components of community empowerment (Hanna Sundari, 2015; Setiawan et al., 2019; Hilman, 2018).

Almost all authors have tendencies to identify community development models and refer to Jack Rothman, who explained three approaches to community development in practice: technical assistance, self, and conflict. In comparison, some call it social actions, the development of locality, and planning social (Pilisuk et al., 1996). Crowfoot and Chesler discuss the community development model from a counter-cultural perspective, a professional-technical perspective, and a political perspective (Jerry W. Robinson \& Green, 2011). Chin and Benne have developed it into a strategic form; planned change: normative-educative, empirical-rational, and coercive power. On the other hand, Green and Haines identified three different models of community development based on a spectrum; self-help, technical assistance, and conflict (Winther, 2015)

However, it refers to Jack Rothman himself that the community development model has been detailed in; local development, social planning, and social action.

Figure 1. The Rothman Intervensi Models

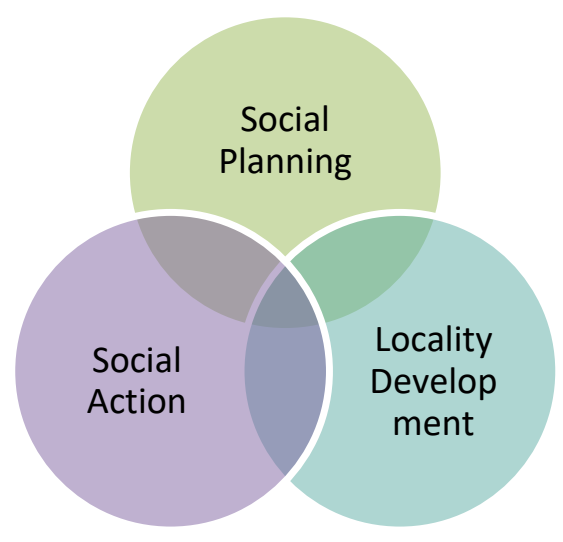

The figure above is initially separated because each model can stand alone, but it can also be integrated (Rothman, 1970). In the empowerment approach, the above model is also called an approach: top-down, button-up, and inside.

\subsection{Kaum as Local Community in Minangkabau}

The togetherness of several individuals above stimulated the idea of this community by sociologists in the twentieth century. Classical sociologists, especially Tonnies, developed the concept of Gesellschaft, and on the other hand, Durkheim took the theme of organic solidarity. The concept of Gesellschaft or organic solidarity together carries the idea that togetherness above is collectivity. Nevertheless, the community is more than just collectivity (Jim Ife, 2009; Rajut et al., 2019). Another sociologist, Bauman, proposed that apart from collectivity, the community will not be separated from the membership factor (member of community). According to him, the idea of membership will have implications for existence; rights, obligations, responsibilities, and several other general purposes. Apart from that, a collectivity must be 
strengthened by a commitment and a sense of belonging, where the individuals in the togetherness recognize each other and are integrated into the community (Jim Ife, 2009).

Jim Ife also commented that the debate that needed to be raised about the concept of community was the multidimensional nature of the community itself. There are three dimensions: geographic location, functionality, and virtuality, where the togetherness is built on the theme in question. An active community is slightly different from a geographic community. In geographic-based communities with strength in the locality, active communities are made possible by relatively easy mobility. Members in this community are no longer restricted by geographic areas but can travel outside their geographic areas to meet other people because of the same interests. In addition to various developments in the conditions of community members that allow for ideas and more comprehensive relations, the negative thing about active or virtual communities is the inherent exclusivity which makes it easier for people to be left and marginalized, especially those who do not have the ability and access to computers, and other skills needed to open access to virtualization (Jim Ife, 2009).

From the collectivity theme above, several words were developed. Therefore, collectivity is defined as organisms that share environments, social groups, social living units, groups, or groups of people, local communities, a collection of various populations (Rhonda Phillips and Robert H. Pittman, 2009; Herlambang, 2015; Rajut et al., 2019; Paramita, 2018; Millennia et al., 2020). Meanwhile, the theme of similarities and differences are defined; interests, interests, goals, and interests. From a geographic, theme is defined as environment, specific area, citizens of a city, tribe, or nation (Herlambang, 2015). The other contentious themes are almost all agreed upon by some recent authors. Some of the points above are pointers to describe community in this context; namely, the community is a group of people aware and committed together in various activities through various media to achieve the same goal. At the same time, this definition rejects the term "community of crazy people" and communities composed of living organisms, such as mangrove communities and other similar communities.

On the other hand, the tribe consists of; a group of several families (nuclear family) that are grouped, based on the lineage of mother, or mother of the mother (grandmother), and usually continue upward from grandmother to grandmother and so on (Jamil, 2019). Such grouping is undoubtedly insufficient to fully describe a Kaum in Minangkabau because perhaps what is mentioned above is only limited to Rumah Tango (household), Jurai, or Paruik (Graves, 2007).

Table 1. Indicator Kaum

\begin{tabular}{ll}
\hline \multicolumn{1}{c}{ Indicator } & \multicolumn{1}{c}{ Description } \\
\hline Grouping based on maternal lineage & The kinship system is built based on women. \\
Having the same social awareness & $\begin{array}{l}\text { Understanding each other in the form of mutual respect } \\
\text { among members of the Kaum and being aware of each } \\
\text { other's social status }\end{array}$
\end{tabular}

Having an heirloom in the form of; land/rice fields/forest/lake, and so on.

The relationship that occurs is emotional.

Interdependent

Having a social structure based on customs and religion

Having a law territorial

Bathing places, cemeteries, rumah gadang, rangkiang (barn) (economic system).

Have a Sako or traditional title.
People at least have an inheritance which is called high inheritance.

This is because the people are a family (extended family).

The needs of members of the Kaum tend to be found or met communally.

The existing social structure is built on religious and customary values.

Jurisdiction of a Kaum recognized by the tribe outside his Kaum

The People must own the completeness.

The people inherit the heirloom titles called Sako. 
The above indicators are very difficult to define this Kaum, but for academic demands based on the above criteria. Kaum, in this article, is a group of people who live together with the matrilineal kinship system, have; autonomous territory and law, socio-cultural structure, and led by someone with the title Datuk. This explanation proves that the Kaum can be said to be a local community in Minangkabau.

\subsection{Social networks}

Social networks in cooperation between people are a sweet form of social capital infrastructure. Communication and interaction spaces become facilitators of social networks to create the strength of cooperation and the growth of trust (Granovetter, 2018). A society will be vital if it has a solid social network. On the other hand, society will become weak if the social network is weak. When individuals meet other individuals, whether they realize it or not, a thick relationship will be built consciously (formally) or unconsciously (informal). Putnam added, when the social network of society is strong, then automatically, the sense of cooperation and participation from the network will help achieve common goals (Putnam, 2002). In interactions that encourage cooperation, the network has a durable network value, which forms solidarity to increase material gain or extended duration (Aberbach et al., 1981).

It can be understood that social networks are relationships that occur between individuals or individuals with groups, or groups with community groups caused by the process of birth, marriage, friendship, or other causes so that they have the potential to work together and build solidarity, in various formal or informal interests. A social network is like an asset. It will not be functional unless actors use it in a community for specific interests. Social capital has three essential functions that create positive effects: benefits through family networks outside the nuclear family, social control, and family support. In an economic context, Fukuyama argues that social networks function to suppress financial capital (Fukuyama, 2000).

\section{Method}

\subsection{Place and time of research}

Nagari Tabek Patah, Salimpuang District, Tanah Datar Regency, West Sumatra Province-Indonesia, was chosen to conduct this research from 2018 to 2019 .

\subsection{Data types and sources}

The consequence of the case study research model is the type of data taken from purposive sampling. These consequences have an impact on data collection techniques through; interviews, documentation, and observation. The data collection tool is aimed at five (5) units Kaum selected based on the traditional considerations of the completeness of the Kaum.

\subsection{Data analysis}

Analysis procedures and data analysis were performed using Yin and Stake logic, namely defining something to investigate, gathering relevant data, analyzing and interpreting the results, and finally drawing conclusions (Yin, 2018; Stake, 1995). The processing of data uses the NVIVO application, and after that, the data is presented and analyzed.

\section{Results and Discussion}

\subsection{Result}

Based on the data collected, a the-based social network is Kaum, as shown in the following figure; 


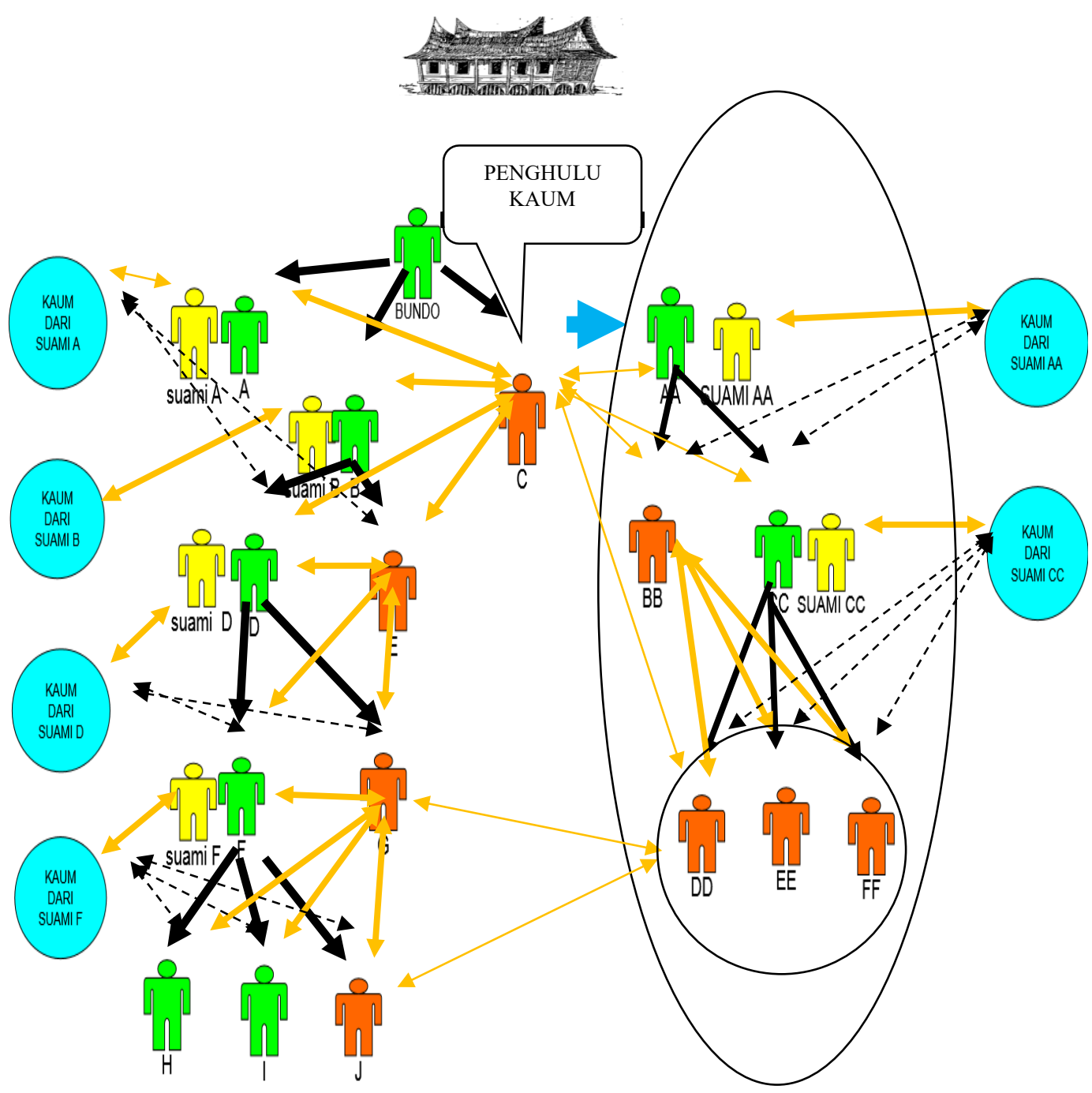

Figure 2. Kaum-Based Social Network in Minangkabau

The picture above shows some components that make up a social network. At the top of the network is called Bundo kanduang, or niniek, the place of origin of the development of the Kaum. Bundo has a strong relationship with the rumah gadang, which is the collection of all his descendants. The descendants from the Bundo to the bottom with black arrows are the core members of the Kaum. A yellow arrow with a picture of a person of color means the relationship between Mamak (maternal uncle) and nephew.

In comparison, the picture of a yellow person is the son-in-law of a tribe due to marriage. On the right-hand side of the picture can be interpreted as members Kaum who are traditionally attached or "malakok." They are not members of the matrilineal lineage but recognized and accepted by local customs. This picture is also has a circle that means their relationship is only limited to normal relations, but it is not related to high inheritance or assets owned by the Kaum they occupy.

\subsection{Discussion}

In some literature, it is not known the meaning of welfare explicitly. However, when looking for equivalent words (synonyms) for welfare, it can be seen that Minangkabau people understand welfare safely, Santoso (prosperous), sanang (happy), baiak, or beautiful (good). Regarding the condition of tangible welfare, it can only be seen in the form of the characteristics attached to the object (Monografi Nagari Tabek Patah, 2015).

The Minangkabau people have an understanding that welfare will not be achieved when they do not adhere to the applicable rules, namely; adat and religion because the relationship between the two is very close and 
Minangkabau people place Islam as the "spirit" and adat as the "body," so that the combination of the two creates a living social life, as opposed to mortal life.

The welfare indicator, according to the view of the Minangkabau community, is the fulfillment of needs; beautiful natural environment; individual needs; family needs; social / community (customary) needs; religious needs; health needs; political taste needs; justice; and security (Monografi Nagari Tabek Patah, 2015).

In terms of livelihoods, the Minangkabau people view nature as providing resources that can be directly utilized or processed first. The process of human and natural interaction in the context of this livelihood in the economic world is known as production (Nasution \& Mahyudin, 2015). According to Ibn Khaldun, there are three factors related to this production: nature, work, and capital. Ibn Khaldun's description implies no difference between nature and capital because nature itself is capital for humans. Meanwhile, human activities or activities in the life cycle are known as work, one of the production factors besides nature (Priyono \& Ismail, 2012).

Of course, the production results are beneficial for the needs of life. However, there is a pattern of managing these results, which is called consumption(Dinar, 2018). The Minangkabau people have long been taught how to manage this consumption. Meanwhile, the products do not have to be spent on needs right away, but there is also investment or savings until the next production comes. The saving is used in any challenging situation, such as in the time of harvest failure. This also applies to the tools used to process nature in work efficiently as possible for smooth work.

The profession played by the Minangkabau people in meeting economic needs is supported by social relations that have been formed through Kaum, as discussed earlier. Social bonding creates a sense of responsibility towards themselves and their families, so that this has resulted in the idea of creating many opportunities to open jobs, both in their hometowns and those living overseas. People in their hometowns from various ways of life above put their family members before other people unless no one is skilled in a needed job. Relation; mamak-kamanakan (mamak-menakan); father's child; brother-in-law; Bako-anak pisang, it is a consideration that dari pado ka urang ancak ka awak (Before (it is given) to other people, it is better (given) to us). Awak (us) is the plural expression of part of me (Monografi Nagari Tabek Patah, 2015; Anggaran Dasar Dan Anggaran Rumah Tangga Kerapatan Adat Nagari ( Kan ) Tabek Patah, 2015). He means he is me, and I am him, then he and I are us (crew). Such patterns adorn the Minangkabau community in an economic dimension (A.A. Navis, 1984).

The Minangkabau community also displayed a unique pattern in building relationships between anak buahinduk semang (employee-employer). Minangkabau people are accustomed to an egalitarian system build relationships that are non-formal rather than formal with their employees. The relationship between the employee and the employer is warm and not rigid, creating a harmonious working atmosphere. This pattern distinguishes the character of the Minangkabau community from other communities. Minangkabau people who become bosses or skippers do not hesitate to eat and sit with drivers or other employees. Not only at work, but this incident also applies at home. Sitting and eating without any distance, whether he is an employer or a worker, is necessary. The Minangkabau community does not differentiate between social status in the economic field but prioritizes togetherness. Ismail Ml. Bagindo, when interviewed, called this term "duduak samo randah, tagak samo tinggi (sitting at the same low, standing at the same height)."

The way of life that has been mentioned above, in principle, has similarities in terms of honesty as an invaluable social network. Even though they do not have financial capital, the Minangkabau people rely on social networks in various businesses. Vegetable traders sell their goods in neighboring provinces such as Riau and Jambi, and the consumers do not always pay cash for their merchandise. They first take them from the farmers, take them to the market, and after they return from trading, all the merchandise is paid to the farmers. This form of trust requires mutual honesty. Farmers honestly show the quality of their agricultural produce, while traders honestly pay for agricultural produce from farmers. Reciprocal in the form of mutual trust is the result of social networking in the kaum.

The preceding will not apply when the trader and the trade owner have a relationship in which there is mutual trust between one another. Social networks are not enough when they do not generate trust. The Minangkabau community will not form partnerships with people they do not trust, even if they are close to family relationships. There is a customary mamangan that is still held concerning this, tibo di mato indak dipiciangkan, tibo di paruik indak di kampihkan (arriving at the eye, (it is) not being closed, arriving in the stomach (it is) not being collapsed). Several informants explained that the intention was to believe and or not 
to believe in someone, which is a sanction imposed on someone after considering the person's behavior and words.

It can be seen that in the economic field, capital is not always material. Mutual trust is born by honest behavior that is continuously cultivated in society. Thus, there should be no reason for society not to do business in various fields if an honest attitude has become an identity.

Conversely, working in the context of the Minangkabau economy requires expertise and skills in their respective fields because someone who is not an expert in their field destroys the job in question and harms others. The point is the professionalism that every human being must have in his life. A person's ability to become a kind of magnet to attract trust from the economic relations are made. Professional individuals will attract more consumers than unprofessional individuals.

The above explanation can compare that the similar kaum in Minangkabau, empowerment model developed Rothman, either approach, or strategy is much more effective when using social network-based people, both from the perspective of button-up, top-down or even inside in various dimensions of empowerment. The combination of these models is as shown below;

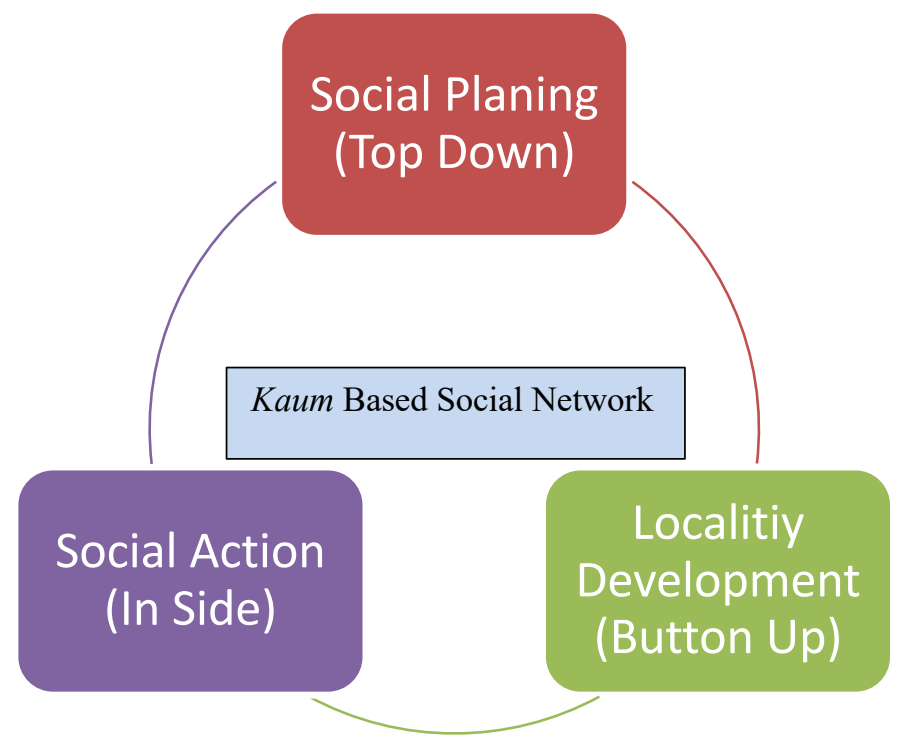

Figure 3. Combinations Model

The model above can be understood that the three Rothman models used in empowering a community either parallelly or partially can be integrated with a community-based network as an approach or as an object of an empowerment program (Hyman, 1990; Pilisuk et al., 1996). The thing that becomes a consideration is that the current community development carried out by various institutions ignores the position of the existing social network among the people. It also has impacts on the effectiveness and success of existing empowerment programs.

\section{Conclusion}

Social networks in the Minangkabau are solid social networks because they were formed through the natural evolutionary process of society. Besides that, social networks, whether permanent or non-permanent based on Kaum, are also supported by customary norms so that the constructed networks become symbols of adat (customary law). However, the network in a community will not have any impact unless used for interest, including community empowerment. For this reason, the strength of social networks in Kaum can be a reference for the management of social networks in various dimensions of community development.

\section{Acknowledgments}

Our gratitude goes to the community leaders of Nagari Tabek Patah and the community members who have helped the author collect data for this research.

\section{References}

A.A. Navis. (1984). Alam Takambang Jadi Guru: Adat dan Kebudayaan Minangkabau. PT Grafiti Pers. 
Abdullah, S. (2013). Potensi dan Kekuatan Modal Sosial dalam Suatu Komunitas. SOCIUS : Jurnal Sosiologi, 12, 15-21.

Aberbach, J. D., Putnam, R. D., \& Bert A. Rockman. (1981). Bureaucrats and Politicians in Western Democracies. Harvard University Press.

ANGGARAN DASAR DAN ANGGARAN RUMAH TANGGA KERAPATAN ADAT NAGARI ( KAN ) TABEK PATAH, Pub. L. No. KAN-TP/VI / 2015 (2015).

BARNETT, T. (2012). SOCIOLOGY AND DEVELOPMENT. HUTCHINSON London.

Dinar, M. (2018). PENGANTAR EKONOMI: TEORI DAN APLIKASI.

Djamaludin Ancok. (2003). Modal Sosial dan Kualitas Masyarakat. Psikologika, 15.

Fukuyama, F. (2000). Social Capital and Civil Society. IMF Working Papers, 00(74), 1. https://doi.org/10.5089/9781451849585.001

Fukuyama, F. (2012). Capital, Civil Society and. World, 22(1), 7-20. https://doi.org/10.1080/01436590020022547

Granovetter, M. (2018). The impact of social structure on economic outcomes. The Sociology of Economic Life, Third Edition, 19(1), 46-61. https://doi.org/10.4324/9780429494338

Graves, E. E. (2007). Asal-usul elite Minangkabau modern: respons terhadap kolonial Belanda abad $X I X / X X$. Yayasan Obor Indonesia.

Hanna Sundari. (2015). MODEL-MODEL PEMBELAJARAN DAN PEMEFOLEHAN BAHASA KEDUA/ASING. PUJANGGA, 1(3), 107-117.

Haridison, A. (2013). Modal Sosial dalam Pembangunan Modal Sosial dalam Pembangunan Anyualatha Haridison. Jispar, 4(1-11).

Herlambang, Y. (2015). Peran Kreativitas Generasi Muda dalam Industri Kreatif terhadap Kemajuan Bangsa. Jurnal Teknologi Informasi Dan Komuniaksi, 2.

Hilman, Y. A. (2018). Model Program Pemberdayaan Masyarakat Desa Berbasis Komunitas Pendahuluan Persoalan Janda, bukan hanya permasalahan stigma yang berkembang di Masyarakat, penyumbang angka perceraian yang tinggi, misalnya Kabupaten Ponorogo, dalam pemberitaan. 6(1), 45-67. https://doi.org/10.1080/13639811.2015.1100863.2

Hyman, D. (1990). Six Models of Community Intervention: A Dialectical Synthesis of Social Theory and Social Action. Sociological Practice, 8(1), 32-47.

Jerry W. Robinson, J., \& Green, G. P. (2011). Introduction to Community Development Theory, Practice, and Service-Learning Edited. In J. Jerry W. Robinson (Ed.), Journal - American Health Care Association (Vol. 3, Issue 3). SAGE Publications, Inc. https://doi.org/10.1093/med/9780198713999.003.0013

Jim Ife. (2009). Human Rights from Below Achieving rights through community development. Cambridge university press.

Millennia, N. I., Anan, Y., Lestari, I., Arifin, R., \& Hidayat, A. (2020). Punk Community in Criminology Study (Study in Ngaliyan District, Semarang City). Law Research Review Quarterly, 6(1), 37-52. https://doi.org/10.15294//rrq.v6i1.31232

Nasution, S., \& Mahyudin (Eds.). (2015). STUDI ISLAM INTERDISIPLINER : Memotret Ilmu Pengetahuan dan Sains Inklusif dalam Islam. Bintang Sejahtera Press.

Palito, M. J. M. (2019). MENGURAI KUSUT: Model Penyelesaian Konflik oleh Penghulu di Minangkabau. Lembaga Pendidikan dan Pelatihan Balai Insan Cendekia. https://doi.org/10.1017/CBO9781107415324.004

Paramita, S. (2018). Pergeseran Makna Budaya Ondel-Ondel Pada. 1(1), 133-138.

Pilisuk, M., McAllister, J. A., \& Rothman, J. (1996). Coming together for action: The challenge of contemporary grassroots community organizing. Journal of Social Issues, 52(1). https://doi.org/10.1111/j.1540-4560.1996.tb01359.x

Priyono, \& Ismail, Z. (2012). Teori Ekonomi. Dharma Ilmu.

ASHREJ Vol. 3, No. 1, 2021: 1-9 
Putnam, R. D. (Ed.). (2002). Democracies in Flux: The Evolution of Social Capital in Contemporary Society. Oxford University Press, Inc., https://doi.org/10.1093/0195150899.003.0006

Rajut, K., Tricoteur, L. E., Surabaya, D. I., Fauzia, A. S., Mardiana, C., Produk, J. D., Teknologi, I., \& Tama, A. (2019). DESAIN MEJA DAN KURSI WORKSHOP PORTABEL UNTUK KOMUNITAS RAJUT DI SURABAYA ( STUDI KASUS : 388-393.

Rhonda Phillips and Robert H. Pittman. (2009). AN INTRODUCTION TO COMMUNITY DEVELOPMENT Edited. Routledge.

Rosalyn Harper. (2001). Social Capital A review of the literature (Issue October, pp. 1-45). Social Analysis and Reporting Division Office for National Statistics.

Rothman, J. (1970). Three Models of Community Practice. Strategies of Community Organization, 20-36.

Setiawan, B., Afandi, M. N., \& Kurniawan, I. (2019). Development Strategy of Village Government with Measurement of Village Building Index in Garut District. 343(Icas), 526-530. https://doi.org/10.2991/icas-19.2019.109

Social Capital: Theory and Research. (2001). In N. LIN, K. COOK, \& R. S. Burt (Eds.), Social Capital: Theory and Research. ALDINE DE GRUYTER. https://doi.org/10.4324/9781315129457

Stake, R. E. (1995). The Art of Case Study Research. SAGE Publications, Inc.

Suharto, E. (2014). Membangun masyarakat, memberdayakan rakyat: kajian strategis pembangunan kesejahteraan sosial dan pekerjaan sosial. PT Refika Aditama.

Syahra, R. (2003). Modal sosial: Konsep dan aplikasi. Jurnal Masyarakat Dan Budaya, 5(1), 1-22.

Winther, T. (2015). What lies within? An exploration of Asset Based Community Development (ABCD) (Issue 1281308). UNITEC New Zealand.

Yin, R. K. (2018). Case study research and applications: Design and methods (Sixth Edit, Vol. 53, Issue 5). SAGE Publications, Inc. https://doi.org/10.1177/109634809702100108 